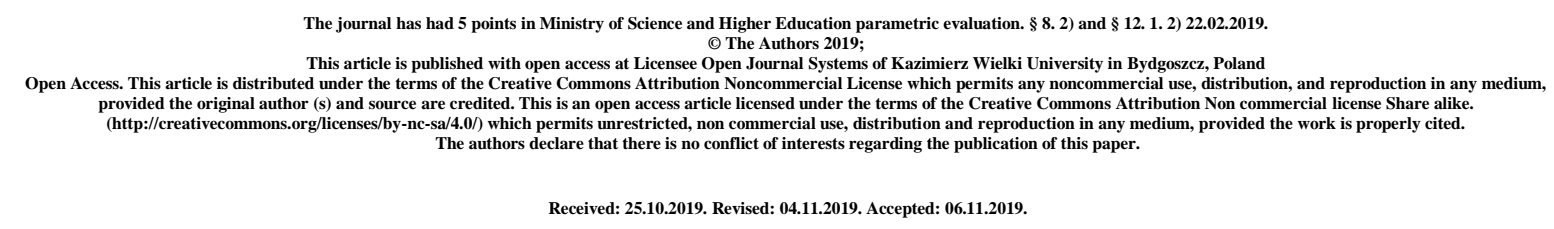

UDC 616.834-002.152-036.1-076.5:575.174.015.3:616-008.811

\title{
Dependence of interleukin-10 quantitative level from genetic polymorphism of toll-like receptors 2 (rs 5743708) in patients with herpes zoster
}

\author{
N. V. Onishchenko, O. V. Riabokon \\ Zaporizhzhya State Medical University \\ Department of Infection Diseases
}

\begin{abstract}
Background. Herpes zoster is urgent problem of the present time, due to increased incidence of severe course with complications in immunocompetent persons, which leads to decrease quality of life and disability. Therefore, the aim of our work was to determine dependence of interleukin-10 concentration on the polymorphism of gene toll-like receptor 2 (rs 5743708) in patients with herpes zoster.

Materials and methods. The study included 50 patients with herpes zoster and 40 healthy people. The quantitative content of IL-10 in serum was determined by enzyme-linked immunosorbent assay, determination of single-nucleotide toll-like receptor 2 polymorphism in whole venous blood was performed by real-time polymerase chain reaction. Statistical processing was performed in program "STATISTICA for Windows 13" (StatSoft Inc., No. JPZ804I382130ARCN10-J).

Results. In patients with shingles were significantly more likely to detect AAgenotype of gene toll-like receptors $2(\mathrm{p}=0.02)$. Also AA-genotype was more frequently detected at moderate course of the disease $(p=0.03)$. It was revealed that in debut of the
\end{abstract}


disease in patients with AA+AG-genotypes, concentration of IL-10 was more highest compared to healthy people and with carriers of GG-genotype $(p<0,05)$. In dynamics there was decrease IL-10 level in serum in all patients, regardless of toll-like receptor 2 gene polymorphism $(\mathrm{p}<0.05)$. On discharge, IL-10 concentration remained elevated in all patients with shingles. It was found that IL-10 concentration in serum patients with herpes zoster at hospitalization had inverse correlation with single nucleotide polymorphism of toll-like receptor 2 gene $(\tau=-0.29, \mathrm{p}=0,01)$.

Conclusions. The AA-genotype of toll-like receptor 2 gene (rs 5743708) is associated with a high chance of reactivation varicella zoster virus and manifestation shingles, moderate course. The allele A of toll-like receptor 2 gene is associated with highest IL-10 concentration, compared with carriers of GG-genotype and healthy people $(p<0,05)$.

Key words: herpes zoster; varicella zoster virus; concentration; interleukin-10; toll-like receptor 2 ; genetic polymorphism.

\section{Introduction}

Recently, herpes zoster has been rapidly spreading, which impairs the quality of life later and in some cases leads to disability [1]. The incidence of herpes zoster in Canada, Japan, Taiwan, and in USA among general population is between 3.4 and 5.0 cases per 1000 population, over 65 years age - from 8.0 to 11.0 per 1000 population. In Europe, this figure is around 2.0-4.6 per 1000 population every year $[2,3]$. The incidence of recurrent herpes zoster is about 14 cases per 1000 population, and mortality rate ranges from 0.017 to 0.465 cases per 100000 population annually [4].

Risk factors for manifestion shingles are immunosuppression, which can be associated with psychological stress, presence of comorbidities, using of immunosuppressive drugs, older age etc $[5,6]$. However, in recent years there has been significant increase incidence rate among young and middle-aged immunocompetent individuals [7, 8, 9], which necessitates further studies on immunopathogenesis of herpes zoster.

A particular role in the immunopathogenesis of virus reactivation and manifestation herpes zoster have cellular immunity, which is a deficiency that leads to increase virusemia and as a consequence dissemination and generalization of infection. It is known that in the regulation of immune response, in particular for infection caused by varicella zoster virus, key place belongs to cytokines and state of their regulatory mechanisms $[10,11]$. Proinflammatory cytokines cause inflammatory process at the local and systemic levels, anti- 
inflammatory - participate in relief of inflammation and regulate severity of defeat [12]. Modern scientists have shown that activity of cytokine production is influenced by toll-like receptors, which are one of the key innate immune signaling receptors of recognition [13]. Toll-like receptors are cell surface glycoproteins that recognize molecular "patterns" and are expressed in cells of myeloid lineage. Activation of toll-like receptors is known to indirectly affect adaptive immunity by stimulating secretion of cytokines, chemokines and other mediators from activated leukocytes. Dysfunction in their signaling system leads to persistence of infections and reactivation of the disease [13, 14].

In our opinion, it is advisable for patients with herpes zoster to find out effect of genetic polymorphism toll-like receptors 2 on the activity of IL-10 production. IL-10 is antiinflammatory cytokine, which is a major inhibitor of inflammation and cytokine cascade [15, 16], inhibits effector functions of macrophages, T-cells, natural killers, neutrophils, is a costimulant of thymocyte proliferation and maturation [15], enhances mast cell synthesis, B-cell proliferation and immunoglobulin secretion, has analgesic effect [16, 17]. Increasing IL-10 level has been shown to be important for the induction of immunity when infected with zoster varicella virus, affecting frequency of disease recurrence and severity of the course $[9,18]$. The peculiarity of toll-receptor receptors 2 type is interaction with a large number of molecules, which provides a variety of recognition for bacterial, viral molecules, fungi and parasites. Expression of toll-like receptors 2 is registered in immune, endothelial and epithelial cells, providing a wide range of functions [13, 14]. In the modern literature, there is a growing body of research devoted to study dependence of IL-10 synthesis on the singlenucleotide polymorphism of toll-like receptor 2 in patients with infectious diseases. Thus, stimulation of toll-like receptors to produce IL-10 suppresses immune system, in particular when infecting pathogens such as Mycobacterium tuberculosis, Candida albicans and some Yersinia species [19]. The effect of activation of toll-like receptors 2 on the synthesis proinflammatory cytokines by herpes virus infections has been investigated [20], but we have not found any studies on the effect of genetic polymorphism of toll-like receptors 2 on the activity of IL-10 production in patients with herpes zoster.

The aim of the study is to determine the dependence of the quantitative level of interleukin-10 on the polymorphism of toll-like receptor 2 gene (rs 5743708) in patients with herpes zoster.

\section{Materials and methods.}

The study included 50 patients with herpes zoster, who were treated in the department № 1 of the municipal institution "Zaporizhzhya Regional Infectious Clinical Hospital of the 
Zaporizhzhia Oblast Council". The age of the patients ranged from 27 to 85 years and was $66.5[55.0 ; 77,0]$ years. Among hospitalized men were 19 (38.0\%), women - 31 (62.0\%). Moderate course of the disease was reported in 35 (70\%) patients, severe - in $15(30 \%)$. All patients underwent traditional clinical laboratory and instrumental study methods. All patients had a negative result of a blood test for antibodies to human immunodeficiency virus. All patients were included in the study on a random basis and informed consent. In the first phase of the study, patients depending on genetic polymorphism of toll-like receptor 2 gene (rs 5743708) were divided into 3 groups: 6 patients with AA-genotype , 2 patients with AGgenotype , 42 patients with GG-genotype of toll-like receptor 2 (rs 5743708). For analysis of the dependence of IL-10 concentration in serum from genetic polymorphism of toll-like receptors 2 type genes all patients were divided: 8 patients with genotypes AA + AG and 42 patients with GG-genotype. The control group consisted of 40 healthy individuals who did not previously have shingles. The age of the control group ranged from 35 to 87 years, was 64.5 $[52.5 ; 73.5]$ years and was not statistically different from the age of examined patients ( $p>$ $0.05)$.

Molecular genetic study of toll-like receptor 2 genes (rs5743708) was determined on a CFX96TM (Bio-Rad Laboratories, Inc., USA) amplifier by real-time polymerase chain reaction using NP-512-100 (RF) kits. The quantitative content of IL-10 in serum was determined by enzyme-linked immunosorbent assay using the high-sensitivity ELISA BMS213HS of human IL-10 (Invitrogen, Austria) and the full-force Sirio-S enzyme analyzer (Seac, Italy). Special studies were carried out at the ZSMU Training and Laboratory Center (headed by Professor A.V. Abramov).

Statistical processing was performed using formed patient database in the program "STATISTICA for Windows 13" (StatSoftInc., No.JPZ804I382130ARCN10-J). The $\chi^{2}$ method was used to compare allele frequencies between different groups. The odds ratio (OR) was calculated by the formula: OR = ad / bc, where a is the frequency of a certain allele in the study group of herpes zoster, b is the frequency of a certain allele in the comparison group, $c$ and $\mathrm{d}$ is the total frequency of other alleles in the study group, and comparison respectively. The limits of $95 \%$ confidence interval (CI) for OR were calculated using the Woolf method [21]. The Mann-Whitney test was used to assess the significance of differences between the quantitative traits in independent groups, Wilcoxon test - in dependent groups. The relationship between the investigated parameters of IL-10 quantitative level and toll-like receptor 2 genotypes (rs 5743708) was determined using Kendall Tau rank correlation method $\tau$. Significantly significant differences were considered at $\mathrm{p}<0.05$. 


\section{Results}

According to the results of our research, it was found that carriage of AA-genotype of toll-like receptors 2 (rs 5743708) were significantly more frequently registered in patients with herpes zoster against the absence this genotype in healthy people who had never previously had this disease (12). \% vs. absence, $\chi 2=7.83, \mathrm{p}=0.02$ ).

A general model of inheritance confirmed the association of genetic polymorphism of toll-like receptor 2 gene (rs 5743708) with reactivation of varicella zoster virus and development of herpes zoster in adults (Table 1).

Table 1. General model of toll-like receptor 2 gene (rs 5743708) inheritance in patients with herpes zoster and healthy people

\begin{tabular}{|c|c|c|c|c|c|c|}
\hline \multirow[t]{2}{*}{ Genotypes } & $\begin{array}{c}\text { Patients } \\
\text { with herpes zoster }\end{array}$ & $\begin{array}{l}\text { Health } \\
\text { people }\end{array}$ & \multirow[t]{2}{*}{$\chi^{2}$} & \multirow[t]{2}{*}{$\mathrm{p}$} & \multicolumn{2}{|r|}{ OR } \\
\hline & $(\mathrm{n}=50)$ & $(n=40)$ & & & value & $95 \% \mathrm{CI}$ \\
\hline Genotype A/A & 0.120 & 0.000 & \multirow{3}{*}{7.83} & \multirow{3}{*}{0.02} & 11.83 & $0.65-216.71$ \\
\hline Genotype A/G & 0.040 & 0.150 & & & 0.24 & $0.04-1.24$ \\
\hline Genotype $\mathrm{G} / \mathrm{G}$ & 0.840 & 0.850 & & & 0.93 & $0.29-2.93$ \\
\hline
\end{tabular}

Notes: $\chi 2$-test, the number of degrees of freedom $\mathrm{df}=2$

It should be noted that AA-genotype of TLR 2 gene (rs 5743708) had impact not only on the manifestation but also on the severity of herpes zoster. Thus, in moderate course, AAgenotype was significantly more frequently detected compared patients with severe course of the disease $(17.1 \%$ vs. absence, $\chi 2=7.26, p=0.03)$. The significantly higher detection rate of AA-genotype of toll-like receptor gene (rs 5743708) revealed in our study allows us to state that the carrier of this genotype is associated with a high chance reactivation of varicella zoster virus and manifestation of herpes zoster, moderate course of the disease $(0,120$ versus $0,00, \mathrm{OR}=11,83,95 \% \mathrm{CI}=0.65-216.71)$. 
Table 2. Dynamics of quantitative content of IL-10 in serum of patients with herpes zoster depending on polymorphism of TLR 2 gene (rs 5743708), Me [Q25; Q75] pg / ml

\begin{tabular}{|c|c|c|c|}
\hline \multirow{2}{*}{$\begin{array}{c}\text { Period of } \\
\text { observation }\end{array}$} & \multirow{2}{*}{$\begin{array}{l}\text { Health } \\
\text { people } \\
(\mathrm{n}=40)\end{array}$} & \multicolumn{2}{|c|}{ Patients with herpes zoster $(\mathrm{n}=50)$} \\
\hline & & $\begin{array}{c}\text { genotypes } \mathrm{AA}+\mathrm{AG} \\
(\mathrm{n}=8)\end{array}$ & $\begin{array}{c}\text { genotype GG } \\
(n=42)\end{array}$ \\
\hline At hospitalization & 0,56 & $\begin{array}{c}6,92 \\
{[4,12 ; 10,88]^{1}}\end{array}$ & $\begin{array}{c}1,68 \\
{[1,00 ; 7,66]^{1,2}}\end{array}$ \\
\hline At discharge & {$[0,37 ; 0,75]$} & $\begin{array}{c}1,06 \\
{[0,82 ; 3,06]^{1,3}}\end{array}$ & $\begin{array}{c}1,00 \\
{[0,66 ; 1,64]^{1,3}}\end{array}$ \\
\hline
\end{tabular}

Notes: 1 - the difference is significant, compared with healthy people (p<0.05); 2 with patients with AA + AG genotypes ( $\mathrm{p}<0.05) ; 3$ - with patients with the corresponding genotype at hospitalization $(\mathrm{p}<0.05)$.

At the next stage of our research we conducted an analysis of the IL-10 quantitative content in dynamics of herpes zoster, depending on TLR 2 gene polymorphism (rs 5743708). At hospitalization in patients with AA + AG genotypes, the IL-10 content was found to be the highest and exceeded this indicator not only in healthy individuals (12.35 times, $\mathrm{p}=$ 0.000006), but also in patients with GG-genotype ( 4.1 times, $\mathrm{p}=0.04$ ) (Table 2).

In the dynamics of herpes zoster on the background of treatment, both in patients with genotypes AA + AG and with GG-genotype there was a decrease IL-10 level in serum (p $<0,05)$. However, it should be noted that on the discharge patients from hospital quantitative content of IL-10 in serum remained elevated in the presence of genotypes AA + AG (1.89 times, $\mathrm{p}=0.04)$, and in patients with the carrier GG-genotype gene TLR-2 (1.78-fold, $\mathrm{p}=$ 0.04) (Table 2).

To confirm the influence of genetic factors on the IL-10 level in the serum of adult patients with herpes zoster, we used the statistical method of Kendall Tau rank correlation. As a result of the analysis, it was found that quantitative content of IL-10 in serum was affected by polymorphism of the TLR 2 gene (rs 5743708). Thus, IL-10 concentration in the serum of patients with herpes zoster at hospitalization was inversely correlated with the single nucleotide polymorphism of the TLR 2 gene (rs 5743708) $(\tau=-0.29, \mathrm{p}=0.01)$, which allows to assert the association of the carrier genotypes AA + AG of TLR 2 gene (rs 5743708) with higher serum IL-10 content. 


\section{Discussion}

IL-10 is important for protecting tissue damage during acute phases of immune responses and can be synthesized by many immune cells and also model the function of these cells $[15,16]$. However, it has been established that the production of IL-10 can be dramatically enhanced by the action on macrophages of immune complexes, resulting to decrease in specific antiviral immunity, which leads to spread and chronicity of infection [22].

Numerous works of scientists prove that toll-like receptors 2 type have both proinflammatory and anti-inflammatory functions. Involvement of toll-like receptors 2 in the action of macrophages, dendritic cells, mediates of IL-10 production, which is one of the strongest anti-inflammatory cytokines [13]. It has been proven that such stimulation suppresses immune system, which in the future has serious consequences in the course of the disease, in development of complications and in period of convalescence [23]. With the advent of molecular genetic studies that help to investigate polymorphism of interleukin genes and toll-like receptors genes, it has become possible to deepen ideas about immunopathogenesis of reactivation of virus varicella zoster and development herpes zoster.

The results of our studies revealed that reactivation of varicella zoster virus and manifestation of herpes zoster, in particular moderate course, were clearly associated with the carrier of AA-genotype of the TLR 2 gene (rs 5743708) ( $\mathrm{p}<0.05$ ). Our studies are to some extent in agreement with the results of other scientific studies proving the influence of tolllike receptors 2 type in manifestation of herpes virus infections, such as cytomegalovirus [20], Epstein-Barr virus, herpes simplex virus [24, 25].

At the same time, we have demonstrated that the TLR 2 gene polymorphism (rs $5743708)$, in particular carriage of allele $\mathrm{A}$, had an inverse correlation $(\tau=-0.29, \mathrm{p}=0.01)$ with serum IL-10 concentration in the debut of disease and was clearly associated with the highest IL-10 level at the hospitalization stage ( $\mathrm{p}<0.05)$.

Other researchers have linked of TLR 2 activity to the quality of immune response when infected with chicken pox virus. The activator activates the synthesis of proinflammatory interleukins (IL-6, IL-8, TNF $\alpha$ ) by TLR 2, the level of production of which causes activity of the inflammatory process and possible development of hepatitis, bronchitis, pneumonia, encephalitis, thrombocytopenia [26]. However, we have not found any scientific papers to investigate the effect of TLR 2 gene polymorphism (rs 5743708) on the activity of IL-10 production in patients with shingles. 


\section{Conclusions}

1. The AA-genotype of TLR 2 gene (rs 5743708) is associated with a high chance of reactivation of varicella zoster virus and manifestation of herpes zoster, moderate course ( 0.120 vs. $0.00, \mathrm{OR}=11.83,95 \% \mathrm{CI}=0.65-216.71)$.

2. In adult patients with herpes zoster in debut of the disease allele A of the gene TLR 2 (rs 5743708) is associated with a higher IL-10 quantitative content in serum, compared with patients-carriers of GG-genotype (4.1 times, $\mathrm{p}=0.04)$ and healthy subjects $(12.35$ times, $\mathrm{p}=$ 0.000006).

\section{References}

1. Kawai K, Gebremeskel BG, Acosta C. Systematic review of incidence and complications of herpes zoster: towards a global perspective. BMJ Open. 2014;4(6):e004833.

2. Koshy E, Mengting L, Kumar H, Jianbo W. Epidemiology, treatment and prevention of herpes zoster: A comprehensive review. Indian J Dermatol Venereol Leprol. 2018;84:251-262.

3. Johnson RW, Alvarez-Pasquin MJ, Bijl M, Franco E, Gaillat J, Clara JG [et al]. Herpes zoster epidemiology, management, and disease and economic burden in Europe: a multidisciplinary perspective. Therapeutic Advances in Vaccines. 2015;3(4):109-120.

4. Yuan Liu. Advances in Epidemiological Studies of Herpes Zoster.J Infection International. 2015;4 (4):116-120.

5. Tseng HF, Chia M, Hung P, Harpaz R, Schmid DS, LaRussa P [et al]. Family history of zoster and risk of developing herpes zoster. International Journal of Infectious Diseases. 2018;66:99-106.

6. Kawai K, Yawn B. Risk Factors for Herpes Zoster: a Systematic Review and Meta-Analysis. Open Forum Infectious Diseases. 2017;4(1): 313-314.

7. Borbinha C, Marto JP, Calado S, Viana-Baptista M. A Young Woman with Ischemic Stroke: Should We Pay More Attention to Varicella Zoster Infection. Case Rep Neurol. 2016;8(2):145-150.

8. Onishchenko NV, Riabokon YuYu, Riabokon OV. The role of interleukin-10 gene polymorphism (rs 1800872) in the course of herpes zoster in adults. Pathologia.2018;15(3): 325-329.

9. Gorishna IL, Volyanska LA, Nykytyuk SO, Mudryk UM, Dyvonyak OM, Goncharuk IYa. Bulozna forma vitryanoyi vispy u dytyny (vypadok iz klinichnoyi praktyky). Zhurnal «Aktualna Infektologiya».2019;7(4): 64-69 [in Ukraine]. 
10. Laing KJ, Ouwendijk W, Koelle DM, Verjans G. Immunobiology of VaricellaZoster Virus Infection. The Journal of infectious diseases. 2018; 218(2):68-74.

11. Hao M, Wang X, Du J, Liu L, Jiao Y [et al]. Cytokine levels are associated with the severity of varicella infections. Infect Dev Ctries. 2015;9(2):190-196.

12. Mubeccel Akdis, Alar Aab, Can Altunbulakli, Kursat Azkur, Rita A Costa, Reto Crameri [et al]. Interleukins (from IL-1 to IL-38), interferons, transforming growth factor $\beta$, and TNF- $\alpha$ : Receptors, functions, and roles in diseases. Journal of Allergy and Clinical Immunology. 2019;138(4):984 - 1010.

13. Kawasaki T, Kawai T. Toll-like receptor signaling pathways. Front Immunol. 2014;5:461.

14. Mallenahally Kusha Vidya, Girish Kumar, Veerasamy Sejian, Madiajagan Bagath, Govindan Krishnan, Raghavendra Bhatta. Reviews Toll-like receptors: Significance, ligands, signaling pathways, and functions in mammals. Journal International Reviews of Immunology. 2018;37(1):20-36.

15. Rojas JM, Avia M, Martin V, Sevilla N. IL-10: A Multifunctional Cytokine in Viral Infections. Journal of Immunology Research. 2017:6104054.

16. Trifunovic J, Miller L, Debeljak Z, Horvat V. Pathologic patterns of interleukin 10 expression-a review. Biochem Med (Zagreb). 2015;25(1):36-48.

17. Hai-Jun Shi, Zhi-Qiang Cui. Correlation of serum inflammatory cytokine and immunoglobulin content with post-herpetic neuralgia in patients with acute herpes zoster. Journal of Hainan Medical University. 2017;23(1):97-100.

18. Beltra J-C, Decaluwe H. Cytokines and persistent viral infections. J. Cytokine. 2016;82:4-15.

19. Suprabhat Mukherje, Subhajit Karmaka, Santi Prasad, Sinha Babu. TLR2 and TLR4 mediated host immune responses in major infectious diseases: a review. The Brazilian Journal of Infectious Diseases. 2016;20(2): 193-204.

20. Jablonska A, Paradowska E, Studzinska M, Suski P, Nowakowska D [et al]. Relationship between toll-like receptor 2 Arg677Trp and Arg753Gln and toll-like receptor 4 Asp299Gly polymorphisms and cytomegalovirus infection. International Journal of Infectious Diseases. 2015; 25: 11-15.

21. Hoppe FM, Hoppe DJ, Walter SD. Explaining odds ratios as conditional risk ratios. Journal of Clinical Epidemiology. 2018;97;123-124.

22. Kugelberg E. Opposing effects of IL-10. Nature Reviews Immunology. 2014; $14: 356-357$ 
23. Jun JC, Jones MB, Oswald DM, Sim ES, Jonnalagadda AR, Kreisman L [et al]. T cell-intrinsic TLR2 stimulation promotes IL-10 expression and suppressive activity by CD45RbHi T cells. PloS one. 2017;12(7):e0180688.

24. Ming-sheng Cai, Mei-li Li,Chun-fu Zheng. Herpesviral infection and Toll-like receptor 2[J]. Prot Cell. 2012;3(8): 590-601.

25. Ma Y, He B. Recognition of herpes simplex viruses: toll-like receptors and beyond. Journal of molecular biology. 2014; 426(6):1133-1147.

26. Wang, Kurt-Jones. VZV activates inflammation cytokines in Human Monocytes and macrophagocytes via TLR2. Journal Virology. 2015; 79(20):12658-12666. 